\title{
Introduction: Needs for New Global Strategies
}

\section{$1.1 \quad$ Is the World Flat?}

Electronics City, an agglomeration of IT companies, lies approximately $40 \mathrm{~min}$ away by road from Bangalore, India. Stepping into the Infosys headquarters located here reveals a world completely different from the rest of India, with its roadside vendors, auto rickshaws, and overwhelming disorderliness. From its expansive campus with its well-manicured lawns, rows of modern buildings, cafeterias, putting greens, and gyms, Infosys provides IT services to the world's largest corporations. Among the striking buildings in the campus, a pyramid-shaped studio located at the center of the campus draws much attention. The studio contains advanced broadcasting equipment and supports a local TV station. This studio enables worldwide connectivity by way of a high-speed satellite link, and the studio's interiors compel one to question their whereabouts. In such a setup, one may feel the world to be flat. Thomas Friedman, a US journalist and author of "The World Is Flat" (Friedman 2005), states that economic activities have enabled the disappearance of national borders in today's world, through ongoing liberalization of international trade and investment brought about by information revolution and organizations such as the WTO. The book mentions Infosys from the outset, stating that the author arrived at the concept of a "flat world" through an interview with the company's former CEO, Nandan Nilekani.

Infosys is said to be one of the top three IT service companies in India, along with Tata Consultancy Services (TCS) and Wipro. Infosys handles offshore IT development of the world's top financial and manufacturing companies and has recently expanded its operations into higher value-added services, such as packaged software development and consulting, through which it is beginning to threaten the business of the world's largest IT service companies such as IBM and Accenture. I have visited the Infosys' Bangalore campus in March 2010, when revenues were still low because of the effects of the financial crisis triggered by the Lehman shock in September 2008. While the impact of the crisis was great, because more than 
$80 \%$ of Infosys' revenues come from western companies, a high percentage of which comes from the financial sector, there was no indication of trouble at Infosys as was among Japanese companies during that period. Though one must discount the self-assured temperament unique to Indians, a review of the 2011 income statement shows that Infosys recorded historically high revenues and profits and that the average pace of revenue and profit growth in the 5-year period beginning in 2007 has remained constant at $20 \%$.

The Infosys campus in Bangalore is connected via the Internet to all parts of the world $24 \mathrm{~h}$ a day, and one can experience a "flattened world" there, with no discernible way of knowing whether one is in India or some other part of the world. However, upon exiting the campus gates, one is immediately pulled back into reality that one is in India. The Infosys campus is visible only as a point on the Google Map, and while this type of "flattened world" may be found scattered throughout Bangalore, these are mere points, and the rest of India is a completely different world which is far from the world described in Thomas Freedman's book.

Immediately before visiting Infosys in Bangalore, the author had the opportunity to visit several corporations at the Neemrana Industrial Park located near Delhi. The park is a 2-h drive away from Delhi, and is home to production operations of various Japanese automotive companies such as Nissin Brake and Mitsui Prime Chemicals. The park has a management committee that comprises companies located there to compile issues arising within the park. The Japan External Trade Organization (JETRO) represents these companies in dealings with Indian government entities. The details on this arrangement can be found in case studies contained in this volume. The author concluded that the companies in the park face several issues that are unimaginable in Japan, such as that of water shortages. The Neemrana Industrial Park is located in the desert state of Rajasthan, where rainwater is scarce. Therefore, the government has imposed water harvesting regulations that prohibit the consumption of groundwater in excess of annual rainfall. The companies here comply with these regulations by increasing their land area in relation to the size of their buildings and reusing wastewater within the park. In addition, the Indian tax system is very complicated, requiring companies to hire local consultants or else run the risk of dealing with local tax authorities. Furthermore, responses to active labor unions are required, and daily electrical outages force companies to install power generation equipment on site. These are some of the many issues faced by companies at Neemrana and across India.

Similar to Infosys, some companies are connected to the world via the Internet with information moving freely without regard to international borders, thereby enabling business transactions on a global level in a flattened world environment. Conversely, companies operating in India face local issues that are unthinkable in Japan, such as of those at the Neemrana Industrial Park. Depending on the industry, type of business, country, or region, the world may indeed be flat and exist as if there were no national borders. However, a world with national borders creates high barriers. In reality, these two worlds co-exist, making it necessary for companies to 
analyze the type and significance of the barriers that exist in the countries and regions they enter, and consider strategies appropriate to the circumstances.

In addition, when devising mid- and long-term strategies, it is important to envision the gradual change of future "barriers" over time. The world is witnessing a gradual decrease in barriers over time; in other words, the world is undoubtedly becoming flatter. For example, India has relaxed its foreign investment regulations, allowing for stimulating foreign firm activity within the country. The Neemrana Industrial Park was created through Japanese-Indian government agreements to promote the local expansion of Japanese parts suppliers of large-scale automobiles and motorbike manufacturers such as Honda and Suzuki, which have production facilities located near Delhi. Through JETRO's representation of the companies in the park with the Indian government, problems that would have been otherwise difficult for smaller companies to solve individually, have a higher probability of resolution. By having a public organization act as an intermediary, investment barriers in India are lowered, thereby producing a relatively flatter world. In August 2011, the Japan-India Comprehensive Economic Partnership Agreement became effective. On the basis of this agreement, it is expected that the operating environment for Japanese companies in India will witness continuous improvement.

The WTO was established in 1995 after replacing the General Agreement on Tariffs and Trade (GATT). Up until that time, trade liberalization efforts such as tariff agreements were conducted through GATT. The areas under negotiation have since broadened, with continued negotiations on creating a level playing field across a range of areas such as government procurement and intellectual property that can become barriers to overseas investment. In addition, free trade agreements and economic partnership agreements, which create deeper economic partnerships on a regional level between countries, are becoming active. Compared with the North American Free Trade Agreement (NAFTA) and the European Union (EU), efforts on regional partnerships had a slow start in Japan; however, with the 2002 economic partnership agreement with Singapore, Japan has gone on to sign agreements with many Asian countries and the Association of Southeast Asian Nations (ASEAN) countries. The aforementioned economic partnership agreement with India developed from these various negotiations, and the trend toward realizing a flatter world is likely to continue.

In "The World Is Flat," Friedman notes that the globalization typified by Infosys is the third historical wave brought about by the IT revolution (Friedman 2005), following the first wave of Columbus discovering new continents and the second wave of improved distribution efficiencies brought about by steam ships and the industrial revolution. The innovations of improved computer performance and information and communication technology via the Internet drastically changed our society and global economy and undoubtedly impacted the flattening of the world. While the barriers of national borders are being lowered by technology through reduced shipping and information transmission costs, the WTO and regional economic partnerships show that the world is also flattening by way of economic systems. 


\subsection{Global Strategies for Emerging Countries}

Japan has a per capita GDP of more than $\$ 50,000$, and a population of over 100 million. It is a superior market from the global perspective, but it lacks prospects for exponential future economic expansion. On the other hand, developing market economies such as China and India are experiencing rapid growth. In 2010, China's nominal GDP was approximately CNY 40 trillion, compared with Japan's JPY 480 trillion. Considering the March 2012 exchange rate of CNY/JPY 13, China's GDP was greater than Japan's at approximately JPY 520 trillion, replacing Japan as the second largest economic superpower in the world. Since the bursting of Japan's bubble economy in 1991, Japan has experienced stagnation on a nominal basis, while the Chinese economy has experienced a phenomenal growth of approximately 2.7 times in real terms in 2000-2010 (an annual growth rate of 10.4\%) and approximately 4.9 times on a nominal basis (an annual growth rate of $17.3 \%$ ) (Fig. 1.1). As of 2010, the Indian economy was positioned at approximately one-third the size of Japan's, and is experiencing profound economic growth as well. During the 2000 2010 period, the Indian economy averaged at a $7.4 \%$ economic growth in real terms

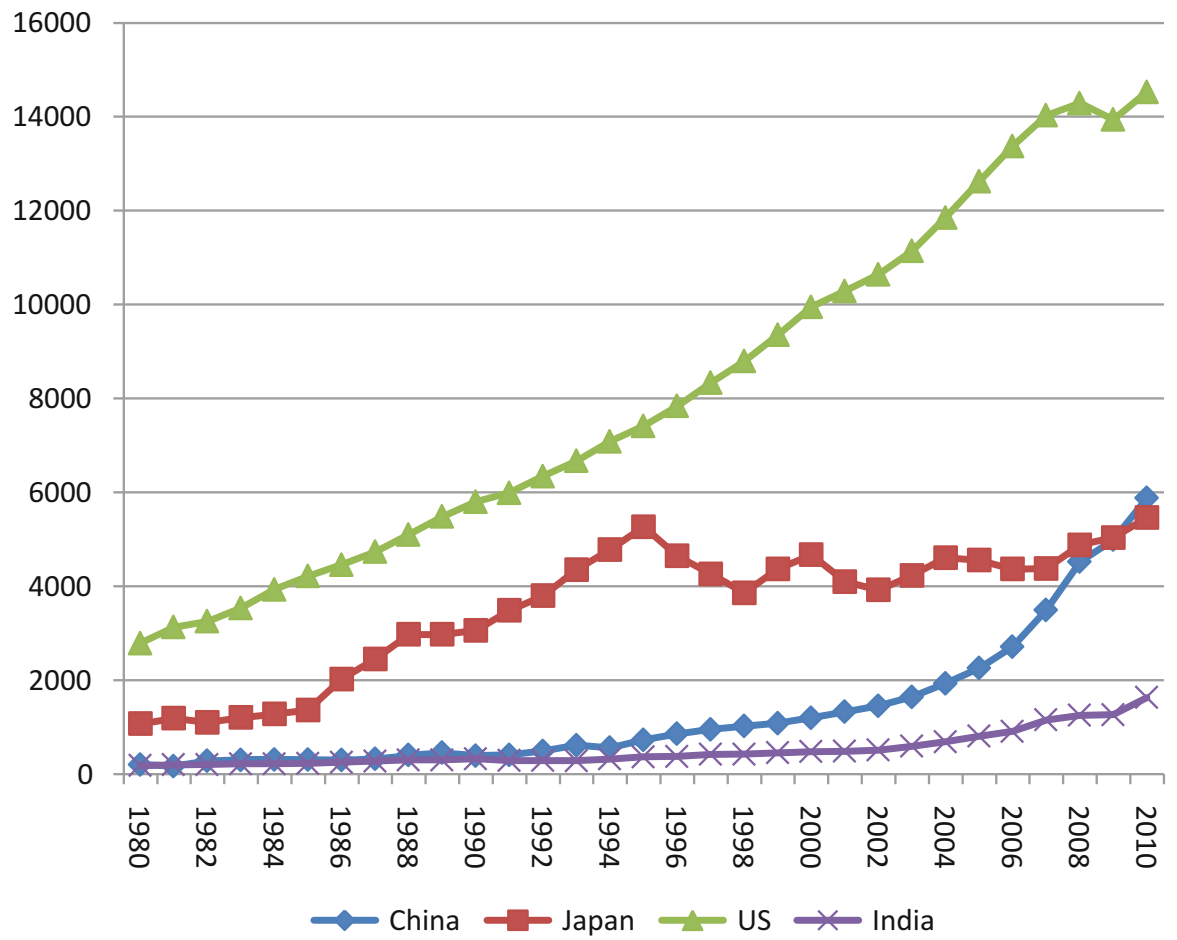

Fig. 1.1 GDP of Japan, the US, China, and India (USD in billions) 


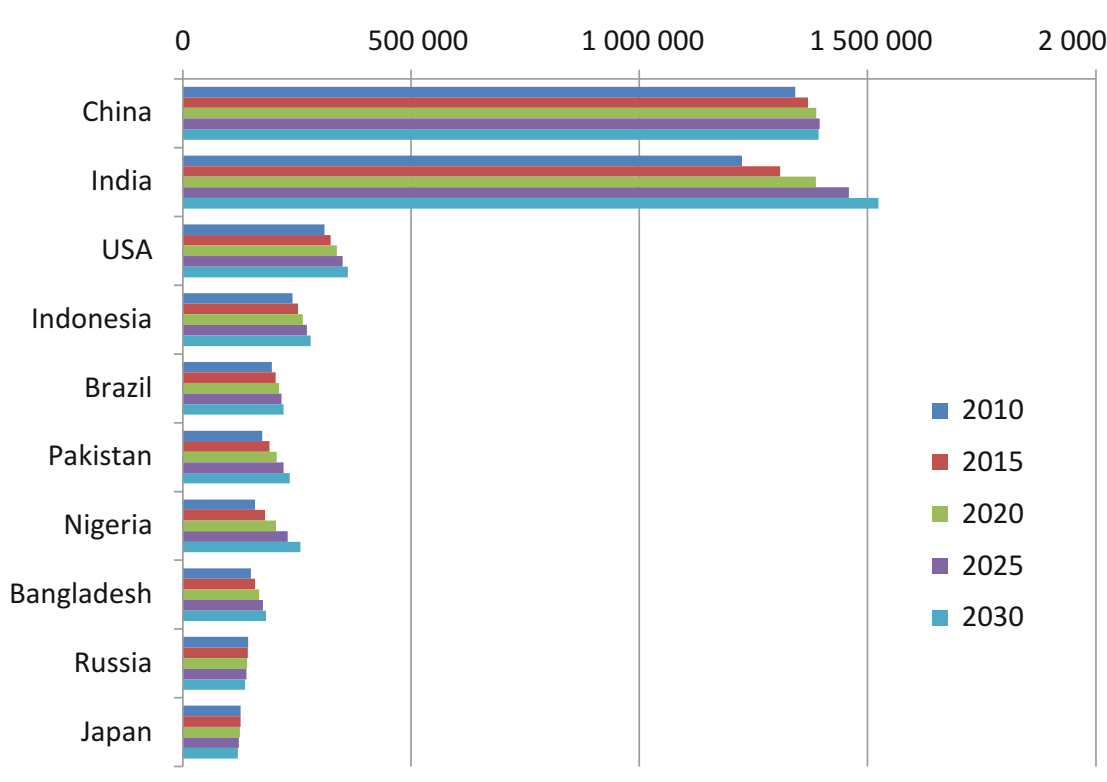

Fig. 1.2 UN population estimates (in order of highest population as of 2010)

(13.3\% on a nominal basis), which, while not as spectacular as that of China, is still consistently strong.

A country's GDP can be subdivided into per capita GDP by dividing the GDP value with the total population. Compared with developed countries such as Japan and the US, China, India, and other developing countries present a higher rate of economic growth because of the improvements in the standard of living and the increase in the per capita GDP exceeding that of the population. This trend is forecasted to continue, and population forecasts for developing nations are optimistic on the whole. Figure 1.2 lists the top 10 countries by population; the US and Japan are the only developed nations that feature on that list. While the US population is estimated to increase in the future, population of Japan is estimated to shrink to the 12th most populous country in the world by 2030. Conversely, while China's one-child policy has resulted in lowering the population growth, India, Indonesia, and other highly populated countries are expected to grow in the future.

Although Japanese markets have reached maturity, developing countries are expected to grow, thereby making their markets attractive. In addition, the world is flattening, and many Japanese companies are taking on the challenges of running global businesses. However, in reality, national borders are still proving to be high barriers, and many companies struggle with operating environments different from those found in Japan. Creating global strategies and a path on the international stage is unavoidable if Japanese companies are to grow in the future, and this growth is possible in developing countries such as China, India, Indonesia, and Brazil rather than developed regions of Europe or the US. With significant differences in 
taxation, regulations, and other aspects of business environments from developed countries, the barriers of national borders in developing countries are higher. Accordingly, overcoming these barriers and seizing business opportunities requires the creation of solid global strategies and innovative business solutions rather than expanding overseas as a simple extension of domestic business models.

\subsection{Perspective of Global Business Strategies}

\subsubsection{Directions of Global Strategies}

How should Japanese companies shape their global business strategies, considering the growing importance of developing nations in the global economy? The economic growth of developing countries such as China and India signifies attractive new markets for Japanese corporations. It is critical to the growth of Japanese companies that they expand into these markets. However, the economic growth of developing countries is the result of their efforts to catch up with developed ones economically. During that process, companies in developing countries will eventually acquire technological capabilities and become major threats to Japanese corporations. These local companies can set competitive prices by providing products and services at low cost by taking advantage of factors such as low local wages. In response to such actions, Japanese corporations must provide greater value to customers to compensate for the price difference in the products and services offered. Competition with these local companies is on a local as well as international level, including Japanese markets. For example, Suntech and JA Power are two Chinese companies with top market share in the production of solar panel. Chinese companies began producing solar panels by implementing full turnkey systems that integrated the solar panel production process from raw materials to the finished product, enabling the production of general-purpose crystalline solar cells with a certain amount of efficiency in electricity generation. The competitive advantage held by manufacturers in developed countries, such as Sharp (Japan) and Q Cells (Germany), was quickly lost because manufacturing technology originally held by panel manufacturers was incorporated into manufacturing equipment. Technologically, Chinese electronics companies and other high-tech industries have quickly caught up and are threatening developed countries' companies, including Japan, that have traditionally differentiated themselves on the basis of their technological prowess. Therefore, while the growth of developing countries presents an "opportunity" for Japanese companies through growing markets, it concurrently poses "threats" through the emergence of competitive local companies.

However, the "threats" by companies electing to forgo global markets and focus exclusively on the domestic market cannot be avoided. Therefore, as Japanese companies aggressively incorporate new "opportunities" into their business models, it is critical that they consider strategies to minimize the damages caused by these "threats." Three important directions of global strategies are as follows: (1) respond to "good-enough" product markets, (2) strengthen cost competitiveness, and (3) create strong business models in which it is difficult to catch up (Fig. 1.3). 
Fig. 1.3 Global business strategy for developing nations

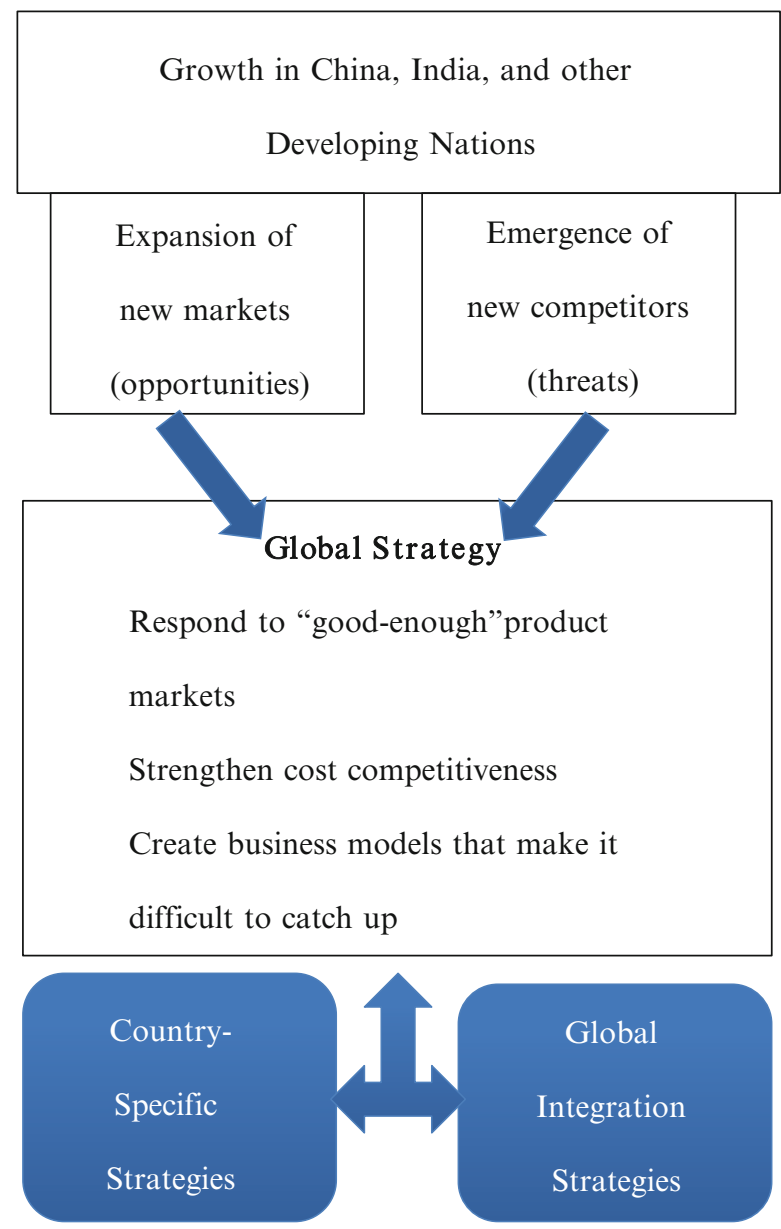

\subsubsection{Products and Services for "Good-Enough" Product Markets}

China is an economic giant that has overtaken Japan to become the world's second largest economy. However, China's population is ten times that of Japan, and the per capita GDP is approximately USD 5,000 or one-tenth that of Japan. On average, the standard of living in China is still low, requiring products appropriate for these circumstances. China has large income disparities, and many households are said to have income greater than the average Japanese household. However, this so-called wealthy class comprises a small part of China's overall population of 1.3 billion. On the other hand, it is not realistic for Japanese companies to compete with local companies for providing products to lower-than-average income classes, given the overwhelming cost competitiveness of local companies. Accordingly, it is more effective for Japanese companies to provide products and services to middle- and 
upper-income classes that have strong purchasing power, despite their relatively low income levels compared with the wealthy class. These middle- and upper-income classes are called a "volume zone" and are witnessing rapid expansion in developing countries such as China and India. For example, in China, high-ticket consumer electronics such as televisions and refrigerators are premium products for the average Chinese; these products were traditionally purchased only by the wealthy. However, China's recent economic growth resulted in growth among the middle class, thereby making these products a common item in most urban homes. These products are sold by local companies such as Haier and Hisense; however, Japanese consumer electronics manufacturers hold high repute for their brands in China. Therefore, if products can be offered at prices that are affordable to the middle class, they are likely to become popular sellers. In addition, products with a certain level of quality and high cost performance attract the wealthy. The market for "goodenough" products by foreign companies in China's consumer electronics market is growing rapidly (Gadiesh et al. 2007).

An important rule in a "good-enough" product market is product development that has just the level of quality demanded by customers. High-quality products will be priced commensurately high, which may be problematic for products that target the volume zone. On the other hand, it is necessary to differentiate premium-priced products from products marketed by local companies. In the "Innovator's Dilemma," Christensen states that when the speed of a product's technological progress exceeds the level of technology demanded by customers, low-priced products with lower functionality and quality (i.e., destructive innovation) enter the market, creating market completion for products that are based on their high level of technology (Christensen 2001). When developing products for developing countries, there is a high likelihood that customer demand for product functionality and quality will be lower than that in Japan. Therefore, it is important for companies to determine the product level that target customers will accept, and develop products at that "goodenough" level.

\subsubsection{Strengthening Cost Competitiveness}

When providing products for "good-enough" markets, it is important to strengthen the cost competitiveness of the overall company. In light of the rise of companies from developing countries such as China, strengthening cost competitiveness is necessary not only for competing in local markets but also for global competition in Japan and elsewhere.

On this point, Japanese companies have been continually working on local production in low-cost regions such as Southeast Asia and China. Overseas production began in earnest among Japanese companies in the mid-1980s, originally as a countermeasure to rising domestic production costs resulting from a stronger yen. Figure 1.4 shows the relationship between various globalization measures such as exchange rate fluctuations, Japanese export volumes, and overseas revenues. The rise in the yen following the 1985 Plaza Accord resulted in an expansion in overseas 


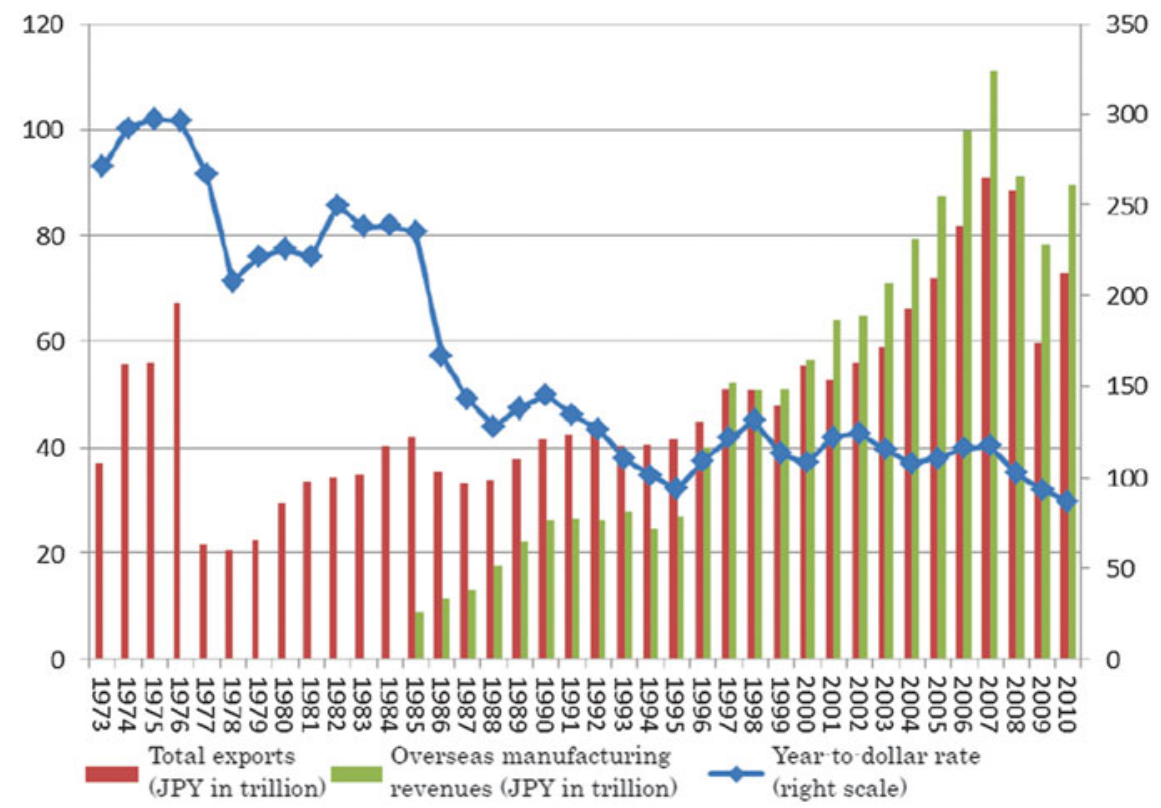

Fig. 1.4 Trends in exchange rates and overseas revenues (Sources: Compiled from "Kaigai Jigyou Katsudou Kihon Chousa” (METI), "Boueki Toukei” (Ministry of Finance))

production. The yen continued to strengthen slowly thereafter, and overseas production resumed rapidly after 2000. In 2000, overseas revenues among manufacturers were greater than export revenues, and while revenues dropped somewhat after the 2008 global financial crisis, they have recently trended upward again.

Figure 1.5 shows the number of subsidiaries, both domestic and foreign, of Japanese companies by year of establishment and country as of 2011. The graph indicates that the movement overseas to developing countries began with investment in New Industrial Economies (NIES) and ASEAN countries. Backed by the strong yen, Japanese electronics manufacturers and automakers began to aggressively enter these regions during the latter half of the 1980s. Investment in China began to grow rapidly thereafter during the 1990s, after China implemented liberalization policies to the outside world and began to aggressively seek foreign investment. During the latter half of the 1990s, the number of overseas subsidiaries drastically reduced, with many companies suspending new overseas investment due to domestic issues resulting from the 1997 economic recession brought about by failures of large economic institutions. In the 2000s, investment in NIES and ASEAN countries remained flat while investment in China again picked up dramatically. This was perhaps brought about by China's entry into the WTO in December 2001 and improvements in China's business environment.

The entry into the overseas market, primarily of production facilities, focused on China as a means to strengthen cost competitiveness. However, wages along China's coastal regions, which have agglomerations of foreign firms, continue to rise, and 


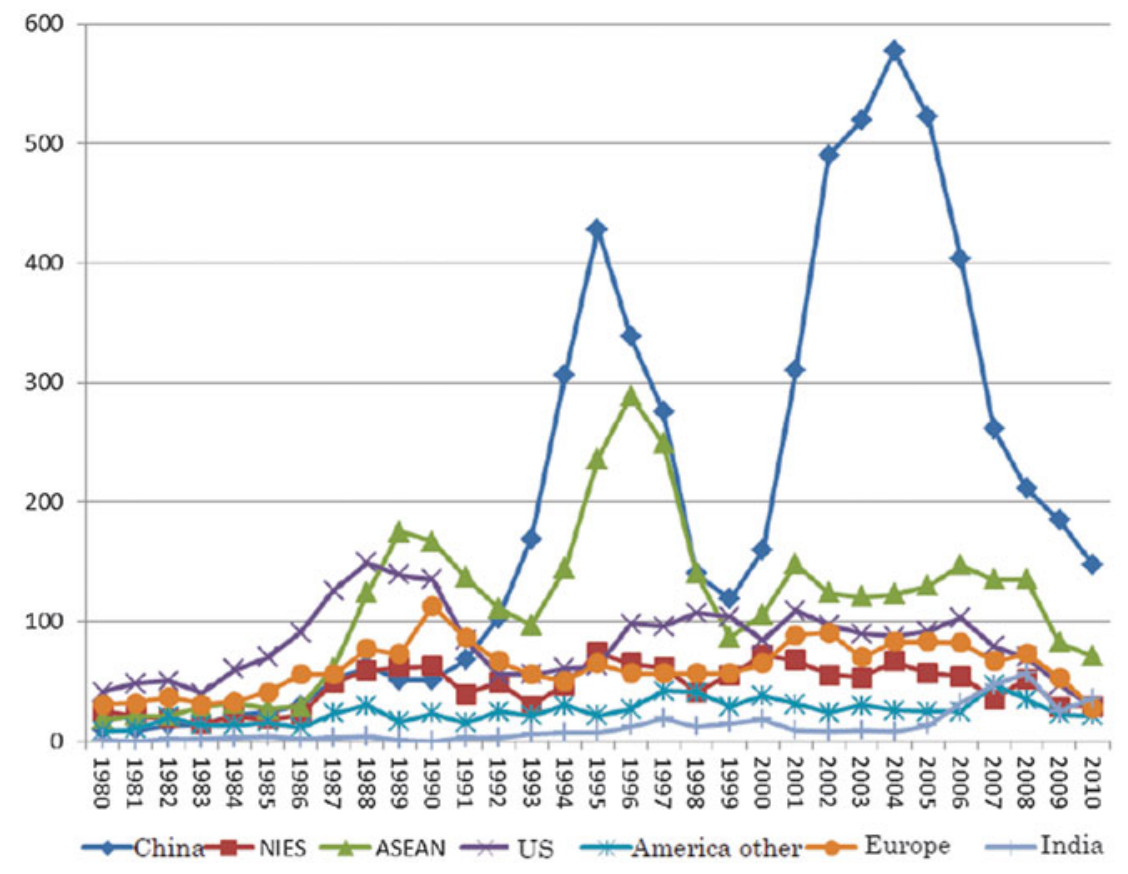

Fig. 1.5 Subsidiaries by country and year of establishment (Source: Compiled from "Kaigai Shinshutsu Kigyou Database 2011" (Toyo Keizai Shinhousha 2011))

more companies are increasingly considering moving to the interior regions of China or to lower-cost countries such as Vietnam. However, when moving production facilities, companies cannot ignore logistical issues such as procurement of raw material and transportation costs, as well as costs associated with investments in production infrastructure and employee training. In addition, companies must consider a host of other factors when selecting new production bases, such as procuring land and dealing with different environmental regulations, tax laws, and investment incentives that are specific to each country.

Japanese companies are in the process of expanding production overseas for many years, although strengthening cost competitiveness of a company as a whole requires the consideration of overseas resources in areas of research and development (R\&D). The results of an international comparison of $R \& D$ within foreign firms in China show that Japanese companies lag behind their European and US counterparts (Motohashi 2011). In terms of management of overseas R\&D centers, Japanese headquarters exert strong control and do not facilitate open innovation between local subsidiaries, local corporations, and universities (Motohashi 2012). Till now, Japanese companies have been cost competitive by transferring production overseas; however, they must also consider the optimal global placement of overall operations, including R\&D. Furthermore, creating partnerships with local firms can be used as a means to strengthen cost competitiveness to drive global business. 
However, joint ventures and strategic alliances increase the possibility of nurturing potential competitors; therefore, costs and benefits should be closely considered when selecting partners and forming alliances.

\subsubsection{Creating Strong Business Models That Discourage Catch Up}

We have discussed market efforts in developing countries and the use of management resources such as personnel within developing countries. However, as preparation for the eventual rise of local companies in developing countries, Japanese companies must create strong business structures that make it difficult for local companies to catch up. First, in terms of technology, every method possible should be exploited to increase the exclusivity of a company's proprietary technology. Policies that enable this exclusivity are as follows: (1) protection by intellectual property rights, (2) protection by know-how (trade secrets), (3) protection by product design complexity, and (4) improvement in the speed of product development. None of these measures fully protect a company's proprietary technology; therefore, inevitably, companies in developing countries will catch up in terms of technology. Therefore, while "product development speed" is critical, generally, open innovation via outsourcing some aspects of development or external partnerships must be used to increase the speed of development. When doing so, companies must provide an overall balance because exclusivity of company's proprietary technology via know-how or design complexity decreases along with outsourcing or partnerships.

The manner in which companies create technology management policies differ in each industry and according to company size. For example, differences in the ability to maintain exclusivity of proprietary technology vary by industry and have been researched in Japanese National Innovation Survey by the Ministry of Education, Culture, Sports, Science and Technology. In this study, "protection by intellectual property rights" was effective for pharmaceutical companies, whereas "product complexity" and "development speed" were important for electronics firms (National Institute of Science and Technology Policy 2004). In addition, small- and medium-sized businesses find it difficult to exercise rights even when they have intellectual property rights for their technology. For example, when a company becomes aware of its patents being violated in China, it becomes difficult for small companies to negotiate with IP violating company, litigate in court as necessary, and then win in court with the implementation of a cease-and-desist order or the payment of licensing fees. In these cases, it is more rational to focus on know-how or other methods rather than intellectual property rights.

In addition, protecting technology is not the only requirement to delay catch up by companies in developing countries. International innovation competition involves multiple players and is not conducted on a one-on-one basis with firms in developing countries. International mergers and acquisitions (M\&As) are more active; for example, Sanyo Electric sold its consumer electronics division to Haier in July 
2011, one of China's largest consumer electronics manufacturers. Sanyo Electric became a wholly owned subsidiary of Panasonic in 2010. The selling decision was made by Panasonic as it already owned a consumer electronics division and was merely rationalizing the overlap of management resources. However, from the perspective of Panasonic and other Japanese consumer electronics manufacturers, undeniably, Haier was able to take a great technological leap through this acquisition. Consequently, even after a company's efforts to fervently protect its technology, leaking of proprietary technology and catching up may happen in various ways. Furthermore, changes in industry structure may result in an inability to differentiate technology. The solar panel case mentioned previously is one such example. Production technology for solar panels was integrated into production equipment as a full turnkey system. Therefore, Sharp, Q Cells, and other manufacturers were unable to differentiate themselves from companies in developing countries through production technology. As a result, Chinese manufacturers such as Suntech and JA Power installed large-scale production equipment and created their own general purpose solar panel market by manufacturing inexpensive products. Of course, in terms of the development of highly efficient solar batteries, companies in Japan, Europe, and the US have superior technology, but mega solar systems (i.e., systems for electric utilities that generate electric power in the megawatts) that are the mainstay of the overall market require many panels across a broad area, making cost more important than efficiency.

Such product commoditization can be observed in flat panel televisions and digital consumer electronics, where completely different business model is required to avoid this situation. To date, Japanese companies have pursued international businesses under a "product" model, in which they develop high-performance products and export them to the rest of world. However, there are some products where this product model is no more effective. In particular, electronic products have a high rate of technological innovation, and generally, latest products often have a higher level of technology than what is demanded by customers (Christensen's Innovator's Dilemma). This makes it easy for local companies to produce destructive innovation, driving Japanese companies out of markets.

Accordingly, a revision of strategies is required in terms of the product model grounded in the idea that "good products sell" to the "customer value" model, in which the proposition of the products' value is made to the customer. A product's value is only realized after its use by the consumer and as such, maximizing its value for money becomes essential. A product's value is gauged after it has been used by customers; therefore, maximization of customer value becomes essential. In the example on solar panels, the largest customers were mega solar operators. The goal of product development in maximizing customer value was not to increase electricity generation efficiency, but rather to increase product durability and simplify maintenance. Thus, the customer value model requires companies to understand their product's value from the customer perspective. In addition, the sale of a product should not signal the end of a relationship; instead, companies must maximize the value of product services through the entire lifecycle of the product. Thus, the "customer value model" is called a "service model." In a commoditized 
business, in which it is difficult to have a product model with an ongoing business, a breakthrough may be possible by differentiating itself with a "service model" that goes back to the basics of customer value.

Furthermore, companies can increase competitiveness by providing multifaceted services for sets of products rather than single products. Returning again to the solar panel example, these panels cost approximately half the total cost of a mega solar system. This is because they require mounts, foundation work, and power control systems. Moreover, critical technology is required to convert the direct current generated by solar panels to alternating current and control unstable electricity to produce stable voltage and frequency. By designing an overall system that could stabilize the current for an extended period beyond the mere panels, companies are able to avoid the commoditization of a single product model. Compared with single products that are easy to copy, such complex services have the benefit of being difficult to replicate because they are large, multifaceted systems comprising multiple products. In pursuing a "customer value model," companies make it difficult for competitors to catch up with these large, complex systems.

\subsubsection{Need for Strategies to Respond to Local Needs}

When creating a global strategy in a flattened world, it is important to acknowledge that local markets, particularly in developing countries, will have barriers of different heights and types. Global strategies indicate pathways to overcome barriers and realize new business opportunities. Methods to overcome such barriers and exploit the differences in the business environments depends on the type of differences between Japanese and local markets. When proposing the Culture, Administration, Geography, and Economics (CAGE) format, Ghemawat states the necessity of analyzing the differences between countries (Ghemawat uses the term "distance") (Ghemawat 2007). CAGE represents culture, administration, geography, and economics, all of which are country specific. Physical distance, as represented by geography, has shrunk with the IT revolution and advancements in transportation technology; however, languages and lifestyle related differences ("Culture") and various economic regulations, tax systems, and regulations on foreign investment (“Administration") still exist as major differences among countries. Therefore, vast economic differences ("Economics") exist in per capita GDP and wages.

Global businesses with operations expanding into new markets are akin to investments in new ventures. In such cases, differences between the home and destination countries are considered as risk factors when making investment decisions. It is possible to estimate physical distance ("G") and economic gaps ("E") with a certain degree of accuracy. In addition, although it is difficult to quantitatively assess cultural differences ("C"), it is possible to estimate them to a certain degree using past case studies, including those from other companies. Thus, the administrative aspect ("A") remains the one area of barriers and differences in global business environment for which risk must be seriously evaluated. For example, in October 2006, companies in Shanghai's Jiading District in China were demanded to leave the area 
without prior notice. The district was designated as a new urban development area headed by the state. Many Japanese companies that became involved in this issue caused the government to also become involved. As of October 2012, this situation remains unresolved. In China, it is possible for the state decision to override a lease agreement for an industrial park, and there have been instances of companies forced to transfer and incur high losses. This example may be extreme, but there have been reports of such incidents in China on a daily basis. The system of contract law, which is the basis for business in developed countries, is imperfect in China; this imperfection is treated as an issue of particularly high risk because of the significant impact on businesses caused by unforeseen changes.

Within developing countries, institutional barriers in business environments arise from domestic circumstances, whether in China, India, or elsewhere. These barriers differ according to the target country. Thus, conducting business operations in China requires an understanding of the institutional imperfections and differences that exist there; the same applies for India and Indian domestic circumstances. Strategies must be created in response to the needs and circumstances of each country.

\subsubsection{Management Strategies Integrated at the Global Level}

Finally, the issue relating to the integration of strategies created for individual countries into a corporation as a whole must be solved. It is important that strategies for developing countries such as China and India, which have significantly different economic environments than developing countries, be specific to the circumstances prevalent in those countries. However, the final objective of management strategies in global businesses should be the optimal use of management resources distributed throughout the world and its integration for the benefit of the company's overall performance. The level of control exerted by headquarters on local entities, or alternatively, the level of delegation to local entities for management decisions, is an issue of concern. Japanese multinational corporations, as compared with those in Europe or the US, are said to be headquarter oriented, with strong management systems exerting stringent controls over local entities (Bartlett and Ghoshal 1989). Until now, Japanese multinationals had focused on expanding production centers overseas. These production centers were managed by transferring production technology from the headquarters to the subsidiaries, resulting in the production of goods that mimicked the parent factory. Therefore, in many instances, the facilities were operated under the tight control of the headquarters. In addition, the productfocused model of "make good products and they will sell" deprioritizes the research of local consumer needs. Accordingly, sales offices were focused on selling existing products rather than gathering information on local consumer needs.

However, capturing the growing "good-enough" product markets in developing countries requires more local R\&D. Using ideas unique to the region to target customers and moving forward with local $R \& D$ that is reflective of local needs cannot be accomplished by way of traditional, one-way decision making, in which decisions flow from the headquarters to local entities. Many large manufacturing 
companies in Japan generate higher revenues overseas. Moreover, an increasingly high percentage of their revenues come from developing countries. However, in such an environment, companies must not treat headquarters and local entities as separate entities, but rather consider corporate-wide strategies on a global basis. Doing so will enable companies to select countries and regions of future expansion and start the process of company-wide integration of strategies based on local area conditions.

\subsection{Structure of This Book}

This book is a summary of theoretical ideas and case studies for corporations in developed countries, including Japan, for designing strategies to maximize opportunities and minimize threats in business expansion into demerging countries. The case studies featured here focus on Asia, including China and India, and use examples of Japanese manufacturers. The examples from China and India are used because of their geographical proximity to Japan and the importance of these two countries in the twenty first century as economic powerhouses in the world economy. However, the theories on global business strategy within this book are, of course, useful when considering business in other developing areas such as Russia, Eastern Europe, or Central and South America.

Japanese companies were used as a starting point to acknowledge how Japanese global corporations, which had conquered the global high-tech product market, should meet the challenges of a new era in developing countries. As stated previously, we have stretched the limits of a product model in which "high-quality products sell," with one solution to this problem being strategic concepts based on service models (i.e., a customer value model). Accordingly, this book contemplates manufacturers in developed countries with relatively high levels of technology. Our main objective is to provide suggestions about requisite technological capability and technology management strategy to respond to the expansion of new markets and the rise of companies in developing countries.

This book deals with macro issues when considering global strategies at a company-wide level. Thus, more practical issues such as the optimum solution to labor issues in China and India or transfer pricing for ROI in local markets are not covered here. However, important issues that develop when pursuing global business are touched upon as much as possible within the case studies to provide a "boots-on-the-ground" perspective.

This book is divided into two sections: the first half deals with global business strategy and the second discusses the fundamentals of strategic planning. Chapter 2 provides an overview of corporate strategy theories and proposes a framework to deepen the understanding of global strategy that acknowledges national barriers. Chapter 3 gives an overview of world economic environment and its long term transition. It is shown that developed country centered world in 1990s becomes to be a divided world between developed and developing economies in 2030. Chapter 4 focuses on the contrasting examples of China and India and examines the strategies 
that reflect the differing institutional characteristics and business environments in these two countries. Chapter 5 discusses global strategies in developing countries and provides an operating model that specifically contemplates competition from developing countries. Furthermore, it explains the strategic planning process through the use of the overseas expansion of infrastructure operations as a case study for the shift from a single product model to a customer value model and of a multifaceted service business, as discussed earlier. Further, Chap. 6 provides a deeper understanding of operating strategy design by using India's Neemrana Industrial Park as a case study of a manufacturing operation with a complex customer value model.

The second half of the book presents some important components to create corporate wide global business strategy, such as strategic alliance, marketing, and technology management theory. Each of these is covered by both theory and case study. Chapters 7 and 8 cover strategic alliance. The theory contained in Chap. 7 begins with the issue of whether to create a wholly owned local subsidiary or partner with a local company, and then discusses management of strategic alliances and publicprivate partnerships (PPPs) for infrastructure businesses. These are examples of alliances with governments of destination countries. Chapter 8 uses Hitachi Construction Machinery (China) Co., Ltd. as a company case study, which made its entry into the market through joint ventures with local companies, but subsequently changed its organization to a wholly owned subsidiary. Next, Chaps. 9 and 10 discuss marketing strategy, with the theoretical part in Chap. 9 explaining standard marketing theory for customer segmentation and targeting before delving into marketing for "goodenough" product markets that are particularly important in developing countries. We also discuss the bottom of the pyramid (BOP) business that targets the poorest classes. The case study discussed in Chap. 10 examines Shiseido's marketing activities in China. Chapters 11, 12, 13 and 14 discuss the theory of technology management strategy within global businesses. The theory discussed in Chap. 11 examines the globalization of R\&D and the management of overseas subsidiaries, followed by a discussion of the characteristics of Japanese companies and their future state with regard to R\&D management within developing countries. Chapter 12 picks up China and India, to see more details of multinationals' R\&D activities in emerging economies. Chapter 13 discusses this further while examining the relationship between Thailand's National Science and Technology Development Agency (NSTDA) and Japanese companies in Thailand as examples of open innovation promotion in developing countries. Chapter 14 examines Suzuki, an exemplary success story among Japanese companies in India, as well as its operating strategy and its integrative local development.

The book concludes with the issue of integrating strategies that differ by country at a global level in Chap. 15. The ultimate goal of management strategy in a global company is to increase a company's overall long-term profitability while expanding internationally. Doing this requires the optimal setting of various parameters appropriate to a company's circumstances, stemming from factors including regional strategies that focus on certain countries or regions, level of headquarter control and the delegation of authority to local entities, and open strategies such as M\&A and 
strategic alliances. In addition, there is no guarantee that strategies that were at one time optimal will continue to remain optimal because of competition or changes in market environment. The ability to optimally adjust strategies in response to changing circumstances is critical when creating and implementing strategies for everchanging developing countries. Furthermore, integrating overseas subsidiaries that operate under varying management environments require diverse managerial abilities; this is done to retain subsidiaries' strength in addition to guidance that encompasses the entire company. Because Japanese corporations tend toward standardized management led by headquarters, we discuss herein the hurdles that must be overcome, as well as the ways to overcome them, to become a truly global company.

Open Access This chapter is distributed under the terms of the Creative Commons Attribution Noncommercial License, which permits any noncommercial use, distribution, and reproduction in any medium, provided the original author(s) and source are credited.

\section{References}

Bartlett, A. C., \& Ghoshal, S. (1989). Managing across borders: The transnational solutions. Boston: Harvard Business Press.

Christensen, C. (2001). The innovator's dilemma: When new technologies cause great firms to fail (trans: Shunpeita, T.). Tokyo: Shoeisha.

Friedman, T. L. (2005). The world is flat: A brief history of the twenty-first century. New York: Farrar Straus \& Giroux.

Gadiesh, O., Leung, P., \& Vestring, T. (2007). The battle for China's good-enough market. Harvard Business Review, 85, 80-89.

Ghemawat, P. (2007). Redefining global strategy. Boston: Harvard Business School Press.

Motohashi, K. (2011, August). Measuring multinational's $R \& D$ activities in China by Patent database: Comparison of European. Japanese and US firms, a paper presented at Academy of Management conference, San Antonio.

Motohashi, K. (2012, June). Managing competency creating $R$ and $D$ subsidiaries: Evidence from Japanese multinationals. TCER working paper series (Working Paper E-48). Tokyo: Tokyo Center for Economic Research.

National Institute of Science and Technology Policy. (2004). Statistics on innovation in Japan (Report on the Japanese National Innovation Survey 2003 (J-NIS 2003)). Tokyo: National Institute of Science and Technology Policy.

Toyo Keizai Shinhousha. (2011). Kaigai Shinshutsu Kigyou Database 2011. Tokyo: Toyo Keizai Shinhousha. 